\title{
Fuel Cell Power Model Elucidates Life-Cycle Costs for Fuel Cell-Based Combined Heat, Hydrogen, and Power (CHHP) Production Systems
}

Team: Darlene Steward and Mike Penev, Hydrogen Technologies and Systems Center

Accomplishment: NREL researchers are now able to model costs for fuel cell-based CHHP systems with accuracy by adding hourly energy-flow calculations to the H2A Hydrogen Production Discounted Cash Flow Model (first reported in April 2009).

Context: Transparent analysis of life-cycle costs for CHHP systems can communicate the benefits of adopting stationary fuel cell technologies. During the early transition phase-in of hydrogen-fueled vehicles, relatively small volumes of hydrogen will be required. Convenient and low-cost refueling could accelerate the adoption of these vehicles. Producing hydrogen in conjunction with electricity and heat may lower the cost of hydrogen production, mitigate investment risk for hydrogen producers, and provide opportunities for small and conveniently located hydrogen refueling stations.

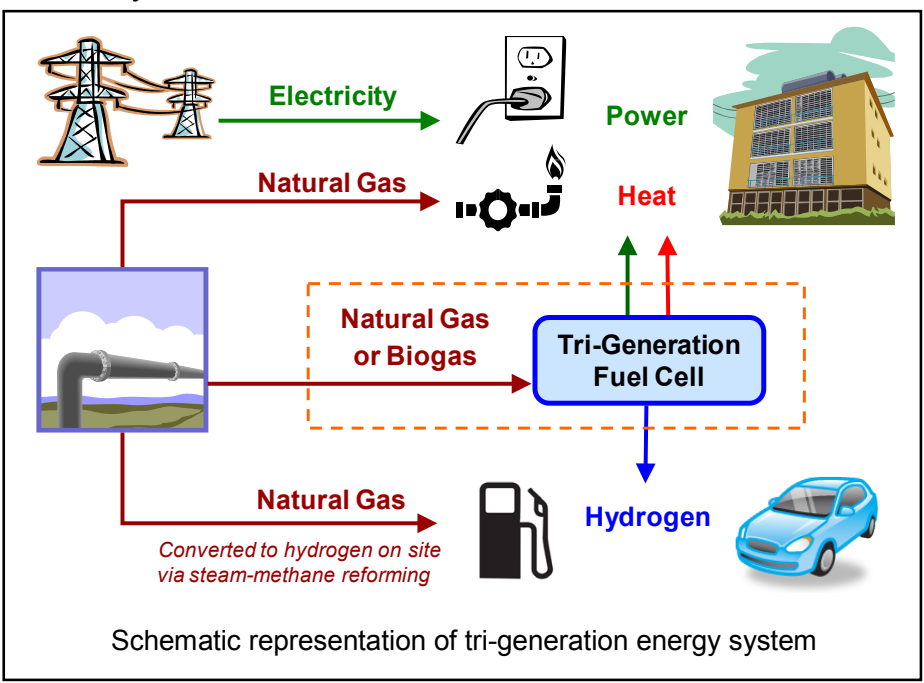

Fuel Cell Power Model (FCPower): The FCPower Model evaluates life-cycle costs for fuel cell-based CHHP systems in an Excel spreadsheet discounted cash flow model. The model provides analysis based on a stationary high-temperature fuel cell fueled by natural gas. The fuel cell produces electricity and heat. Hydrogen can also be produced by purifying it from the exhaust gas from the fuel cell. These products provide some of the electricity and heat needed by a nearby building.

Electricity can be generated more efficiently by the fuel cell than by conventional technologies, and the use of the waste heat from the fuel cell to supply some of the building's requirements for space and hot water heating further increases the overall efficiency of the system.

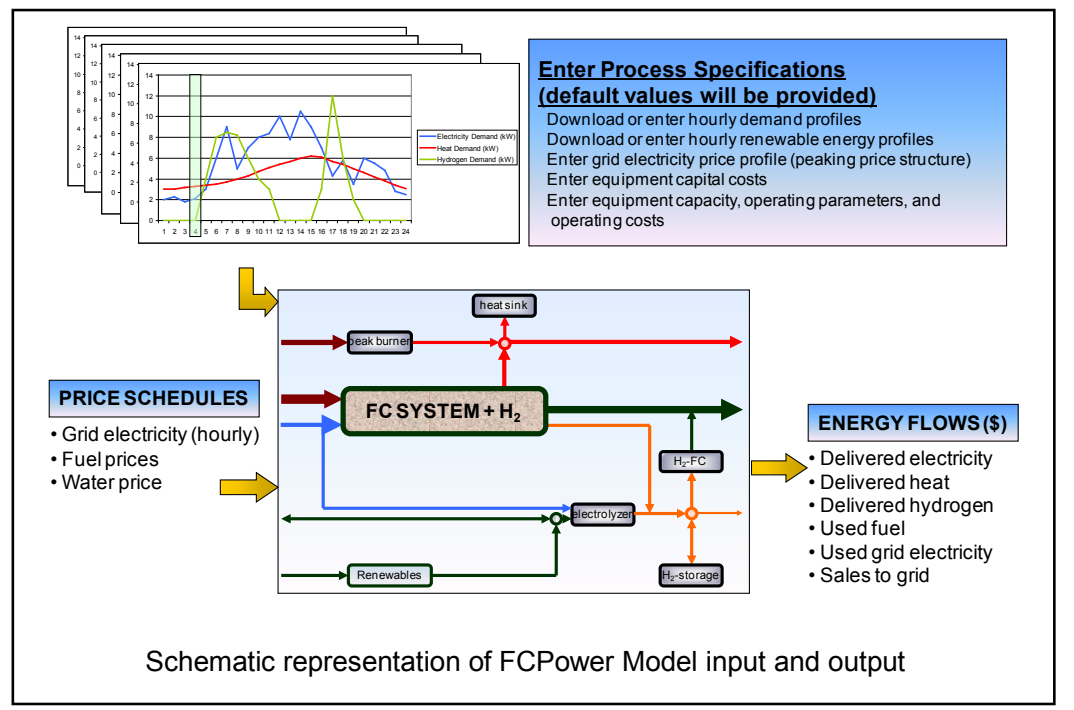

\begin{abstract}
NREL researchers have developed two versions of the FCPower Model. One uses a molten carbonate fuel cell as the primary technology, and the other uses a phosphoric acid fuel cell. Incorporating an hourly energy analysis module, the model analyzes the response of the fuel cell and associated equipment to hourly electricity, heat, and hydrogen demands. Users can enter different demand profiles for various buildings. The energy-analysis module calculates the fuel usage, electricity, heat, and hydrogen production from the system for each hour for one year. The hourly data are then aggregated and input into the life-cycle discounted cash flow calculations in the model to determine the annualized cost to produce energy from the system over its lifetime.
\end{abstract}

Significance of Accomplishment: Uncertainty in hydrogen demand for the early-transition phase increases investment risk and costs for hydrogen production and distribution. Combining hydrogen production with CHP capability may reduce upfront costs and investment risk. Development of the FCPower Model allows analysis of new early-transition strategies and facilitates transparent and consistent cost comparisons with standalone hydrogen production facilities. These new strategies can also be incorporated into city and nationwide transition scenario analyses. The energy analysis output from the model can be used to estimate primary energy usage and greenhouse gas emissions benefits for fuel cell CHHP systems in comparison with conventional energy production. 